\title{
Accumulation of organotin compounds in the common whelk Buccinum undatum and the red whelk Neptunea antiqua in association with imposex
}

\author{
I. Ide ${ }^{1}$, E. P. Witten ${ }^{1}$, J. Fischer ${ }^{2}$, W. Kalbfus ${ }^{3}$, A. Zellner ${ }^{3}$, E. Stroben ${ }^{4}$, \\ B. Watermann ${ }^{1, *}$
}

${ }^{1}$ LimnoMar, Bei der Neuen Münze 11, D-22145 Hamburg, Germany

${ }^{2}$ Eco-Research Program, Memorial University, St John's, Newfoundland, Canada A1C 5S7

${ }^{3}$ Bayerisches Landesamt für Wasserwirtschaft, Institut für Wasserforschung, Kaulbachstr. 37, D-80539 München, Germany ${ }^{4}$ Universität Münster, Institut für spezielle Zoologie und vergleichende Embryologie, Hüfferstr. 1, D-48149 Münster, Germany

\begin{abstract}
Several species of the subclass Prosobranchia are considered to be suitable organisms for monitoring long-term effects of triorganotin (TOT) compounds. This study utilized Buccinum undatum and Neptunea antiqua from the North Sea and the Irish Sea. Morphological alterations in the genital system (imposex phenomena), the histological structure of the gut, and the gonads were studied. TOT concentrations in soft body tissue and shells were determined. Females of both species displayed imposex phenomena (pseudohermaphroditism). The percentage of altered females per station ranged from 0 to $90 \%$ in B. undatum and from 0 to $29 \%$ in $N$. antiqua. Imposex index values in B undatum reached 1.09 near Helgoland and 0.86 in $N$ antiqua sampled at 25 nautical miles from the Scottish northeast coast. Organotin compounds were detected in the soft bodies of snails from all stations. A chi-square analysis revealed a significant correlation between imposex stages and TOT concentrations in $B$. undatum but not in $N$. antiqua. Tributyltin (TBT) in $B$. undatum ranged from 1.0 to $15.9 \mathrm{ng} \mathrm{g}^{-1}$ wet weight (Irish east coast). TBT concentrations in $N$. antiqua were higher and ranged from 2.2 to $25.7 \mathrm{ng} \mathrm{g}^{-1} \mathrm{In}$ both species, organotin compounds in the shells were below detection limits. Despite high TBT concentrations in soft tissues and the occurrence of imposex (offshore and inshore), female gonads were in good shape and no signs of limited reproductive capacity were found. Histological findings indicate that TBT does not contribute considerably to mortality in the common whelk
\end{abstract}

KEY WORDS: Molluscs · Organotin compounds - Accumulation · Imposex · Antifouling · Deep sea

\section{INTRODUCTION}

Some studies on inshore marine environments present evidence that the common whelk Buccinum undatum, like other Prosobranchiata (e.g. Nucella lapillus), is specifically sensitive to triorganotin compounds such as tributyltin (TBT) and tripentyltin (TPT) (Stroben 1994, Mensink et al. 1996b). Since the distribution area of $B$. undatum ranges from the lower intertidal zone to

\footnotetext{
-Addressee for correspondence.

E-mail: 100571.643@compuserve.com
}

the deep-water zone the snails are considered as suitable invertebrates for the monitoring of long-term effects caused by TBT-containing biocides (ten Hallers-Tjabbes 1979, Gibbs \& Bryan 1986, ten HallersTjabbes et al. 1994, 1996)

In previous studies, the bulk of female snails displaying imposex phenomena (also called psuedohermaphroditism, the development of additional male sex organs on females; Smith 1971) were found inshore, especially near harbours (Bauer et al. 1995). The aim of this study was to evaluate: (1) whether snails obtained from offshore sampling stations accumulate triorgan- 
Table 1. Details of sampling stations and numbers of snails studied. SB: soft-body; NM: nautical miles

\begin{tabular}{|c|c|c|c|c|c|c|c|c|c|}
\hline \multirow{2}{*}{$\begin{array}{c}\text { Station } \\
\text { no. }\end{array}$} & \multirow{2}{*}{$\begin{array}{l}\text { Sampling } \\
\text { station }\end{array}$} & \multirow[t]{2}{*}{ Position } & \multirow{2}{*}{$\begin{array}{c}\text { Distance } \\
\text { to coast } \\
\text { (NM) }\end{array}$} & \multirow{2}{*}{$\begin{array}{l}\text { Depth } \\
\text { (m) }\end{array}$} & \multirow{2}{*}{$\begin{array}{l}\text { Date of } \\
\text { sampling }\end{array}$} & \multicolumn{2}{|c|}{ Buccinum undatum } & \multicolumn{2}{|c|}{ Neptunea antiqua } \\
\hline & & & & & & $\begin{array}{l}\text { No. of } \\
\text { snails } \\
\text { studied }\end{array}$ & $\begin{array}{c}\text { No. used } \\
\text { for chemical } \\
\text { analysis of } \mathrm{SB}\end{array}$ & $\begin{array}{l}\text { No. of } \\
\text { snalls } \\
\text { studied }\end{array}$ & $\begin{array}{c}\text { No. used } \\
\text { for chemical } \\
\text { analysis of SB }\end{array}$ \\
\hline 1 & Helgoland & $\begin{array}{l}54^{\circ} 09.00^{\prime} \mathrm{N} \\
07^{\circ} 47.50^{\prime} \mathrm{E}\end{array}$ & 25 & 40 & $\begin{array}{l}5 / 95 \\
8 / 95\end{array}$ & $\begin{array}{l}18 \\
20\end{array}$ & $\begin{array}{l}5 \\
7\end{array}$ & - & - \\
\hline 2 & Fisher Bank & $\begin{array}{l}56^{\circ} 41.36^{\prime} \mathrm{N} \\
05^{\circ} 12.29^{\prime} \mathrm{E}\end{array}$ & 110 & 20 & $\begin{array}{l}1 / 95 \\
9 / 95\end{array}$ & $\begin{array}{l}74 \\
15\end{array}$ & $\begin{array}{r}12 \\
0\end{array}$ & $\begin{array}{c}4 \\
-\end{array}$ & 2 \\
\hline 3 & $\begin{array}{c}\text { English NE } \\
\text { coast }\end{array}$ & $\begin{array}{l}55^{\circ} 26.91^{\prime} \mathrm{N} \\
00^{\circ} 21.74^{\prime} \mathrm{W}\end{array}$ & 43 & 65 & $\begin{array}{l}1 / 95 \\
6 / 95\end{array}$ & $\begin{array}{l}3 \\
1\end{array}$ & $\begin{array}{l}3 \\
1\end{array}$ & $\begin{array}{l}4 \\
9\end{array}$ & $\begin{array}{l}3 \\
6\end{array}$ \\
\hline 4 & $\begin{array}{l}\text { Scottish E } \\
\text { coast }\end{array}$ & $\begin{array}{l}56^{\circ} 18.26^{\prime} \mathrm{N} \\
01^{\circ} 56.76^{\prime} \mathrm{W}\end{array}$ & 25 & 35 & $6 / 95$ & 27 & 7 & 17 & 6 \\
\hline 5 & $\begin{array}{l}\text { Scottish NE } \\
\text { coast }\end{array}$ & $\begin{array}{l}57^{\circ} 48.16^{\prime} \mathrm{N} \\
01^{\circ} 16.37^{\prime} \mathrm{W}\end{array}$ & 22 & 75 & $6 / 95$ & - & - & 17 & 5 \\
\hline 6 & $\begin{array}{l}\text { English NW } \\
\text { coast }\end{array}$ & $\begin{array}{l}54^{\circ} 21.94^{\prime} \mathrm{N} \\
03^{\circ} 51.03^{\prime} \mathrm{W}\end{array}$ & 12 & 35 & $6 / 95$ & 11 & 5 & - & - \\
\hline 7 & $\begin{array}{l}\text { Irish } E \\
\text { coast }\end{array}$ & $\begin{array}{l}52^{\circ} 35.00^{\prime} \mathrm{N} \\
06^{\circ} 04.67^{\prime} \mathrm{W}\end{array}$ & 9 & 25 & $6 / 95$ & 36 & 9 & 2 & 1 \\
\hline 8 & $\begin{array}{l}\text { St. George's } \\
\text { Chamnel }\end{array}$ & $\begin{array}{l}51^{\circ} 15.62^{\prime} \mathrm{N} \\
06^{\circ} 15.73^{\prime} \mathrm{W}\end{array}$ & 52 & 110 & $6 / 95$ & 1 & 0 & 3 & 1 \\
\hline 9 & $\begin{array}{c}\text { Inner English } \\
\text { Channel }\end{array}$ & $\begin{array}{l}50^{\circ} 49.47^{\prime} \mathrm{N} \\
00^{\circ} 46.91^{\prime} \mathrm{E}\end{array}$ & 6 & 20 & $6 / 95$ & 23 & 9 & - & - \\
\hline
\end{tabular}

otin (TOT) compounds comparably to the inshore samples cited above; (2) whether snails from offshore stations display imposex phenomena; and (3) if the presence of TOT in snails coincides with imposex phenomena. The present investigation focused on 2 species for the biological effect monitoring, Buccinum undatum and Neptunea antiqua. Morphological alterations of the genital system were studied to determine different imposex stages. Unfortunately, alterations of the female genital organs occur not only as a result of high TOT concentrations but can also be caused by parasites, diseases and noxious substances (Myint \& Tyler 1982, Reid 1986). The state of health of selected individuals was determined by histological examination of the alimentary tract, the midgut gland and the gonads, thus estimating the possible involvement of causes of imposex phenomena other than TOT (Knickmeyer \& Steinhart 1989, Lauckner 1980). TBT, dibutyltin (DBT) and monobutyltin (MBT) were determined in soft-body tissue. Hereinafter, TOT represents the sum of TBT + DBT + MBT. The shells of $B$. undatum were also analyzed, to determine whether organotin compounds are accumulated by hard tissue.

\section{MATERIAL AND METHODS}

Study area. Buccinum undatum $(n=229)$ and $N e p-$ tunea antiqua $(n=56$ ) were caught on a random basis at 9 different stations in the North Sea and the Irish Sea
(Fig. 1, Table 1) during cruises no. 155 (January 1995) and no. 161 (June 1995) of the RV 'Walther Herwig' (sampling stations 2 to 9). Snails from Str 1 were collected by members of the Biologische Anstalt Helgoland (May, August and September 1995).

Determination of imposex. The snails were relaxed using $7 \%$ magnesium chloride dissolved in demineralized water. The shell and aperture height was mea-

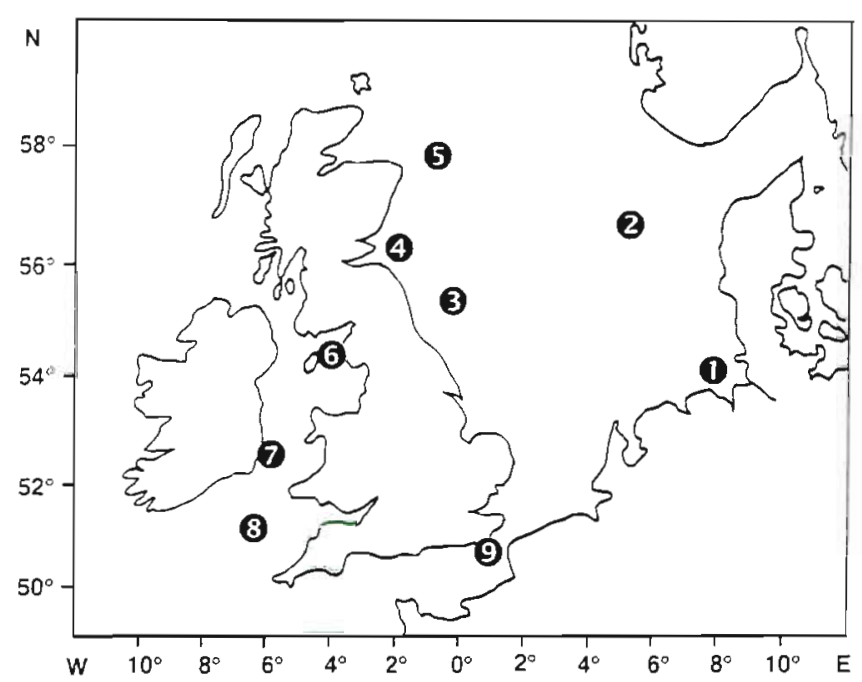

Fig. 1. Study area. (1) Helgoland, (2) Fisher Bank, (3) English northeast coast, (4) Scottish east coast. (5) Scottish northeast coast, (6) English northwest coast, (7) Irish east coast, (8) St. George Channel, (9) inner English Channel. 
sured to the nearest $0.1 \mathrm{~mm}$ and soft tissue was removed from the shells. The individual's sex, the degree of imposex development, and alterations of the genital tract were determined using a dissecting microscope. The degree of imposex was determined for females of both species according to the criteria described in detail previously for Buccinum undatum by Stroben (1994): Unaltered females are assigned to the category 0 . Those females that develop penis-like structures are classified based on the size of the induced 'penisanlage' into categories $1 \mathrm{a}, 2 \mathrm{a}$, and $3 \mathrm{a}$. Those females that develop a vas deferens are classified based on the degree of its phenotypic expression into categories $1 \mathrm{~b}$ and $3 \mathrm{~b}$ ( $2 \mathrm{~b}$ was not observed). Whelks that develop both attributes are assigned to category 4 (no category 4 females were observed in this study).

The imposex index was calculated following the criteria of Gibbs et al. (1987), Stroben et al. (1992a, b), and Oehlmann et al. (1992): $\frac{\sum \text { (no. of females in category) } \times \text { (category no.) }}{\text { Total no. of female snails }}=$ imposex index

Determination of TOT compounds. TBT, DBT, and MBT were determined following the protocol of Uhler et al. (1984). Analysed organs in both species were the midgut-gland gonad complex in Buccinum undatum and the midgut-gland and gonad in Neptunea antiqua. In addition, shells of $B$. undatum obtained from $\mathrm{Hel}$ goland and Fisher Bank were analysed for TOT compounds (5 shells each). These measurements were carried out with wet and dried tissues. Results were given in $n g g^{-1}$ wet weight (ng $g^{-1}$ dry weight for hard tissue). Concentrations of organotin compounds in $B$. undatum determined in dried tissues correlated with the concentrations measured in wet tissues $(r=0.990)$. The average organotin concentration in samples of dried tissue was $2.73( \pm 0.24$, SD) times higher than in samples of wet tissue. Correlation ( $r$ ) of TOT concentrations in dried and wet tissues of $N$. antiqua ranged between 0.973 and 0.990 and average organotin concentration in dried tissues was $3.28( \pm 0.16)$ times higher than in wet tissues.

Impact of TOT concentrations on imposex phenomena. To examine whether a significant relation existed among the sum of TBT, DBT and MBT concentrations and imposex development for each snail species, a chisquare analysis was performed on all available specimens regardless of the sampling station. Three categories of TOT concentrations were chosen: (1) minor $\leq 12.5 \mathrm{ng} \mathrm{g}^{-1}$ (TOT 1), (2) medium: $>12.5 \mathrm{ng} \mathrm{g}^{-1}$ and $\leq 25 \mathrm{ng} \mathrm{g}^{-1}$ (TOT 2), and (3) high: $>25 \mathrm{ng} \mathrm{g}^{-1}$ (TOT 3). Occurrence of the 4 different imposex stages $(0,1,2,3$; see above) at the 3 different levels of TOT concentrations were tabulated and chi-square calculation (Sachs 1988) carried out.
Histological studies. Histological studies of the midgut-gland gonad complexes were performed on 20 Buccinum undatum obtained from Helgoland and Fisher Bank (10 snails each). The specimens were fixed in Bouin's solution, then placed in $70 \%$ propanol, dehydrated in graded ethanol solutions and subsequently embedded in hydroxyglycol-methacrylate (Technovit 7100, Kulzer). Sections (5 $\mu \mathrm{m}$ thick) were stained with haematoxylin-eosin (Böck 1989).

\section{RESULTS}

\section{Analysis of TBT, DBT, and MBT compounds}

Butyltin compounds were found in soft tissues of snails from all examined sampling stations (Fig. 1, Table 2). In Buccinum undatum, the average TBT concentrations of soft tissues ranged between $1.0 \mathrm{ng} \mathrm{g}^{-1}$ off the English northeast coast and $15.9 \mathrm{ng} \mathrm{g}^{-1}$ of $\mathrm{f}$ the Irish east coast (Table 2); the latter was also the site where the highest TBT content in a single specimen was found $\left(\mathrm{TBT}=47.0 \mathrm{ng} \mathrm{g}^{-1}\right)$. Moreover, Table 2 reveals that average concentrations of TBT at different sampling stations varied considerably more (factor of 15.9) than average concentrations of DBT and MBT (factors of 5.4 and 4.2 , respectively). In general the rank of concentrations in tissue homogenates was MBT > DBT > TBT (Table 2). Two individuals out of $62 \mathrm{~B}$. undatum (1 from the Fischer Bank, 1 from the English west coast) contained TBT concentrations below the detection limit of $2 \mathrm{ng} \mathrm{g}^{-1}$ soft tissue. Butyltin concentrations in all shells were less than $2 \mathrm{ng} \mathrm{g}^{-1}$.

In Neptunea antiqua, the average TBT concentrations of soft tissues ranged from $2.2 \mathrm{ng} \mathrm{g}^{-1}$ off the English east coast to $25.7 \mathrm{ng} \mathrm{g}^{-1}$ wet weight off the Scottish northeast coast (Table 2). The highest content of TBT in a single specimen (TBT $=120.5 \mathrm{ng} \mathrm{g}^{-1}$ ) was observed at the latter station, 25 nautical miles (NM) offshore. Similar to Buccinum undatum, average TBT concentrations at different sampling stations varied considerably more (factor of 15.1) than average concentrations of DBT and MBT (factors of 9.6 and 5.4, respectively). One out of 26 examined individuals of $N$. antiqua (English northeast coast) contained a TBT concentration below the detection limit of $2 \mathrm{ng} \mathrm{g}^{-1}$

\section{Occurrence of imposex}

In both snails, morphological alterations of the female genital organs were restricted to imposex phenomena. Table 3 shows the calculated imposex indexes for Buccinum undatum and Neptunea antiqua as well as the percentage of altered females, the occur- 
Table 2. Buccinum undatum and Neptunea antiqua. Concentrations of organotin compounds in soft tissues

\begin{tabular}{|c|c|c|c|c|}
\hline Sampling station & $\begin{array}{c}\text { TBT } \\
\left(\mathrm{ng} \mathrm{g}^{-1} \text { wet wt }\right) \\
\bar{x}(\min -\max )\end{array}$ & $\begin{array}{c}\text { DBT } \\
\left(\text { ng g } g^{-1} \text { wet } w t\right) \\
\bar{x}(\min -\max )\end{array}$ & $\begin{array}{c}\text { MBT } \\
\text { (ng g } g^{-1} \text { wet wt) } \\
\bar{x}(\min -\max )\end{array}$ & $\begin{array}{c}\operatorname{TOT} \bar{x} \\
(\Sigma \mathrm{TBT}, \mathrm{DBT}, \mathrm{MBT}) \\
\left(\mathrm{ng} g^{-1}\right)\end{array}$ \\
\hline \multicolumn{5}{|l|}{ Buccinum undatum } \\
\hline Helgoland & $4.9(1-14)$ & $15.8(4.1-28.0)$ & $14.7(6.6-30.0)$ & 35.4 \\
\hline Fisher Bank & $1.4(0-3.3)$ & $3.6(0.0-8.6)$ & $9.2(2.4-21.0)$ & 14.2 \\
\hline English NE coast & $1.0(0.8-1.4)$ & $3.5(1.4-5.6)$ & $6.4(2.8-9.0)$ & 10.9 \\
\hline Scottish E coast & $2.7(0.9-4.6)$ & $2.9(1.5-5.2)$ & $4.2(3.1-7.6)$ & 9.8 \\
\hline English W coast & $1.1(0-3.3)$ & $3.4(0.0-7.7)$ & $3.5(2.5-4.4)$ & 8.0 \\
\hline Irish E coast & $15.9(1.3-47.0)$ & $11.2(4.1-18.0)$ & $10.7(6.6-16.0)$ & 37.8 \\
\hline Inner English Channel & $2.6(1.0-4.0)$ & $5.8(2.5-12.0)$ & $6.3(4.5-8.3)$ & 14.7 \\
\hline \multicolumn{5}{|l|}{ Neptunea antiqua } \\
\hline Fisher Bank & $3.6(2.0-5.1)$ & $3.1(1.0-5.2)$ & $7.6(7.1-8.1)$ & 14.3 \\
\hline English E coast & $2.2(0.0-7.5)$ & $3.1(0.5-10.0)$ & $4.2(2.1-5.9)$ & 9.5 \\
\hline Scottish E coast & $25.7(0.9-120)$ & $29.9(0.5-129)$ & $6.1(2.7-10)$ & 61.7 \\
\hline Scottish NE coast & $10.3(0.8-38.0)$ & $6.4(2.8-9.6)$ & $19.6(6.9-43.0)$ & 36.3 \\
\hline Irish E coast & 10.0 & 8.6 & 8.4 & 27.0 \\
\hline St. George Channel & 1.7 & 4.3 & 3.6 & 9.6 \\
\hline
\end{tabular}

Table 3. Buccinum undatum and Neptunea antiqua. Sex ratio, percentage of females displaying imposex phenomena, imposex indices and observed imposex stages

\begin{tabular}{|c|c|c|c|c|c|c|c|c|}
\hline \multirow[t]{2}{*}{ Sampling station } & \multicolumn{4}{|c|}{ Buccinum undatum } & \multicolumn{4}{|c|}{ Neptunea antiqua } \\
\hline & $\begin{array}{l}\text { Males' } \\
\text { females }\end{array}$ & $\begin{array}{l}\text { Females with } \\
\text { imposex }\end{array}$ & $\begin{array}{l}\text { Imposex } \\
\text { index }\end{array}$ & $\begin{array}{l}\text { Observed } \\
\text { imposex } \\
\text { stages }\end{array}$ & $\begin{array}{l}\text { Males/ } \\
\text { females }\end{array}$ & $\begin{array}{l}\text { Females with } \\
\text { imposex }\end{array}$ & $\begin{array}{l}\text { Imposex } \\
\text { index }\end{array}$ & $\begin{array}{c}\text { Observed } \\
\text { imposex } \\
\text { stages }\end{array}$ \\
\hline Helgoland & $18 / 19$ & $90 \%(17$ of 19$)$ & 1.90 & $0,1 a b-3 a$ & - & - & - & - \\
\hline Fisher Bank & $62 / 26$ & $12 \% \quad(3$ of 26$)$ & 0.11 & $0,1 \mathrm{a}$ & $3 / 1$ & - & - & 0 \\
\hline English NE coast & $0 / 4$ & $75 \% \quad(3$ of 4$)$ & $(1.30)$ & $0,1 b, 3 a$ & $2 / 11$ & $18 \%(2$ of 11$)$ & 0.55 & $0,3 \mathrm{a}$ \\
\hline Scottish E coast & $13 / 13$ & $8 \% \quad(1$ of 13$)$ & 0.08 & $0,1 a$ & $7 / 10$ & $0 \%(0$ of 10$)$ & 0.00 & 0 \\
\hline Scottish NE coast & - & - & - & - & $10 / 7$ & $29 \%(2$ of 7$)$ & 0.86 & $0,3 \mathrm{a}$ \\
\hline English NW coast & $4 / 7$ & $0 \% \quad(0$ of 7$)$ & 0.00 & 0 & - & - & - & - \\
\hline Irish $\mathrm{E}$ coast & $14 / 21$ & $10 \% \quad(2$ of 21$)$ & 0.29 & $0.3 \mathrm{a}$ & $0 / 2$ & (1 of 2$)$ & $(1.00)$ & $0,2 \mathrm{a}$ \\
\hline St. George Channel & - & - & - & - & $1 / 2$ & $(2$ of 2$)$ & $(1.00)$ & $1 \mathrm{a}$ \\
\hline Inner English Channel & $14 / 9$ & $67 \% \quad(6$ of 9$)$ & 1.11 & $0,1 a b, 2 a$ & - & - & - & - \\
\hline
\end{tabular}

ring imposex stages, and the male/female ratio. The percentages of females with imposex are shown in Table 3.

In Buccinum undatum, the highest percentages of altered females were found off Helgoland and in the inner English Channel. High percentages of altered females were also observed at stations located 43 and 110 NM offshore, i.e. the English east coast and Fisher Bank. Unaltered females were found at the sampling station with the lowest TOT concentration, i.e. the English northwest coast.

In Buccinum undatum, a chi-square analysis, performed on all individuals which were used for TOT analysis, revealed a significant dependence $\left(\chi^{2}=\right.$ 12.95, $v=6, \alpha=0.05)$ of the degree of imposex phenomena on concentrations of TOT ( $\Sigma$ TBT, DBT, MBT) in soft tissues (Table 4).
The highest percentage of altered females of $N e p$ tunea antiqua was observed off the northeast coast of Scotland. No altered females were found off the Scot-

Table 4. Buccinum undatum. Numbers of females (pooled samples) displaying no imposex phenomena (imposex stage 0), and imposex stages 1, 2, and 3 (see 'Materials and methods') at different TOT concentrations in soft tissues (TOT $1=$ low, TOT 2 = medium, TOT 3 = high; see 'Materials and methods')

\begin{tabular}{|c|c|c|c|c|c|}
\hline & \multicolumn{4}{|c|}{ Imposex stage } & \multirow[t]{2}{*}{ Sum } \\
\hline & 0 & 1 & 2 & 3 & \\
\hline TOT 1 & 1.7 & 2 & 0 & 2 & 21 \\
\hline TOT 2 & 13 & 4 & 3 & 0 & 20 \\
\hline TOT 3 & 9 & 3 & 2 & 6 & 20 \\
\hline Sum & 39 & 9 & 5 & 8 & 61 \\
\hline
\end{tabular}


tish east coast in spite of the snails' high TBT concentrations. At the St. George Channel station (52 NM off the coast) only 2 snails were examined, but both displayed imposex phenomena. A correlation between the concentrations of TOT and the degree of imposex phenomena (as found for Buccinum undatum) was not found for $N$. antiqua.

\section{Histological observations}

The testes and ovaries of Buccinum undatum generally displayed no pathological alterations. The female gonads contained unripe and ripe oocytes; signs of disturbance of oogenesis were not observed. The tubules of the midgut-gland were in good shape and capable of digestion (holding phase). Two specimens from the Helgoland station contained trematodes. Consequently, autolysis and degeneration of the gonads and the midgut-gland were observed.

\section{DISCUSSION}

TBT, DBT and MBT were found in soft tissues of both species from all sampling stations. No sampling station was situated nearer to the coast than $6 \mathrm{NM}$. Even in snails obtained at a distance of more than $100 \mathrm{NM}$ from the coast, measurable amounts of TOT compounds were detected. Organotin contents in Neptunea antiqua were higher than in Buccinum undatum. In a previous investigation on common whelk carried out in the North Sea, ten Hallers-Tjabbes et al. (1996) found TBT residues of 2.5 to $28.8 \mathrm{ng} \mathrm{g}^{-1}$ dry weight. These results are comparable to our results (Table 2 ), as are the results of Mensink et al. (1996a) which indicate 11.5 to $11.8 \mathrm{TBT}_{\mathrm{ng} \mathrm{g}}{ }^{-1}$ dry weight for the common whelk from the Eastern Scheldt (The Netherlands).

The mean TBT concentrations per station varied considerably in both species (factor of 15.1 to 15.9 ) whereas DBT and MBT concentrations varied much less (factor of 4.2 to 9.6). Comparison of TBT, DBT, and MBT accumulation in Buccinum undatum and Neptunea antiqua from identical stations also indicated that TBT was the most variable TOT compound. The correlation of TBT concentrations between both species was low ( $\mathrm{r}=0.126$ ) but higher correlations were calculated for DBT ( $r=0.456)$ and MBT ( $r=0.874)$, Why are the values of TBT concentrations so variable within and between both species? A possible explanation might lie in the finding that several Prosobranchiata species concentrate up to $50 \%$ of the total TBT accumulated in the female gonads (Oehlmann et al. 1992, Stroben 1994) and thus probably release TBT with spawning. This assumption is supported by Knick- meyer \& Steinhart $(1989,1990)$ who demonstrated that concentrations of cyclic organochlorines in $B$. undatum and $N$ antiqua show seasonal variations due to the deposition of vitelline in oocytes. If TBT is deposited in a similar manner, it is likely that its concentrations are subject to seasonal variations according to the phase of the reproductive cycle. Furthermore, there is evidence that incorporated TBT occurs as a transitory chemical in the snail's soft tissues and undergoes a biotransformation (TBT $\rightarrow$ DBT $\rightarrow$ MBT), preferentially in the digestive gland (Bryan et al. 1993). In our data there is a decrease in concentration from MBT to DBT to TBT in the body tissues which supports the suggested metabolic pathway.

Imposex in Buccinum undatum has been reported in recent studies by several authors. Altered females were observed in the Arctic (Brick \& Bolte 1994), on the coast of Brittany (Stroben 1994) and in southeast Asia (Svennen et al. 1996). In the open North Sea and along the coast of The Netherlands imposex is now a common phenomenon (ten Hallers-Tjabbes 1996), in contrast to findings from studies carried out 18 yr ago along the coast of The Netherlands (ten HallersTjabbes 1979), when no altered females of $B$. undatum were observed. In the present study, altered females of both species were found at all sampling stations, with only 2 exceptions: the English northwest coast with no altered B. undatum, and the Scottish east coast with no altered Neptunea antiqua. Even though a significant dependence of the degree of imposex phenomena on concentrations of TOT in soft tissues (Table 4) was shown for B. undatum, a high occurrence of imposex phenomena did not necessarily coincide with high average TOT values at different stations. The highest percentages of altered female $B$. undatum were not found at the station with the highest average TOT values (Irish east coast) but off Helgoland, the station with the second highest average TOT values, where $90 \%$ altered females displayed all kinds of imposex stages. Very high percentages of altered females $(67 \%)$ were also found in the English Channel with medium average TOT contents (Table 3 ). Females obtained from other sampling stations were less affected. However, off the Irish east coast (45 NM offshore) females with very high average TOT contents in soft tissues and high imposex stages (up to 3a) were observed, although a relatively low percentage of the females (only $10 \%$ ) were altered.

On the other hand, the TBT body concentration in Neptunea antiqua of the Scottish east coast was high but none of 13 examined females displayed any sign of imposex. Laboratory experiments of Mensink et al. $(1996 b, c)$ revealed that TBT had no impact on adult females but induced the development of male reproductive organs in juveniles. This indicates the exis- 
tence of a sensitive phase for TBT influence on the gonad in the development of the snails, a time-window phenomenon known from a variety of endocrine disrupters (Colborn \& Clement 1992). As TBT concentrations at the time and sites of juvenile development of the examined snails are unknown, the observed ambiguities concerning TBT concentrations and occurrence of imposex in adults are not surprising after all, even if there is a strong relationship between TBT concentrations and imposex during juvenile development. The results of our histological investigations are in agreement with the findings of Stroben (1994) and Mensink et al. (1996c), that TBT has no impact on adult female Buccinum undatum. Despite often high TBT concentrations in soft tissues and the occurrence of imposex (offshore and inshore), female gonads were in good shape and no signs of limited reproductive capacity were found

Data presented by Hagena (1991) and by Michaelis (1993) indicate that Buccinum undatum is already extinct in large coastal areas of The Netherlands and off the east Frisian coast. By 1970 , the abundance of $B$. undatum was severely reduced, primarily due to overfishing. Although the fishery was closed, the snail population never recovered (Neudecker 1990, Michaelis 1993). As maturation and sexual development in other snail species are influenced by TOT compounds (Matthiessen et al. 1991, Bauer et al. 1995), the possibility has been discussed that increasing tributyltin pollution may also contribute to the decrease of populations of B. undatum (Cadée et al 1995, ten HallersTjabbes \& Boon 1995). However laboratory experiments carried out by Mensink et al. (1996c) and our histological findings indicate that TBT does not contribute heavily to mortality in the common whelk.

Acknowledgements. This investigation was carried out in cooperation with $V$ Dethlefsen and $T$ Lang (Federal Research Board of Fisheries, Germany) and M. Ruth (Institute of Marine Research, Kiel) and by the Biologische Anstalt Helgoland. The research was founded by the WWF-World Wide Fund of Nature (Germany) and the Aktion Seeklar (Germany)

\section{LITERATURE CITED}

Bauer B, Fioroni P, Ide I, Liebe S, Oehlmann J, Stroben E, Watermann $B(1995)$ TBT effects on the female genital system of Littorina littorea: a possible indicator of tributyltin pollution. Hydrobiologia 309:15-27

Böck P (1989) Romeis mikroskopische Technik, 17 Aufl. Urban \& Schwarzenberg, München

Brick M. Bolte M (1994) Cytology of the outer penis epithelium of Buccinum undatum (L.) from the arctic region - an observation of the imposex phenomenon. Helgoländer Meeresunters 48:123-131

Bryan GW, Bnght DA, Hummerstone LG, Burt GR (1993) Uptake, tissue distribution and metabolism of ${ }^{14} \mathrm{C}$-labelled tributyltin (TBT) in the dog-whelk, Nucella lapillus. J Mar Biol Assoc UK 73:889-912

Cadée GC, Boon JP. Fischer CV, Mensink BP, ten HallersTjabbes CC (1995) Why the whelk (Buccinum undatum) has become extinct in the Dutch wadden sea. Neth J Sea Res 34:337-339

Colborn T, Clement C (1992) Chemically-induced alterations in sexual development: the wildlife/human connection. In: Colborn T, Clement $\mathrm{C}$ (eds) Chemically-induced alterations in sexual and functional development: the wildlife/ human connection. Advances Modern Environ Toxicol, Vol 21, Princeton Scientific Publishing Co, Inc, Princeton, NJ, p $1-6$

Gibbs PE. Bryan GW (1986) Reproductive failure in populations of the dog-whelk, Nucella lapillus, caused by imposex induced by tributyltin from antifouling paints. J Mar Biol Assoc UK 66:767-777

Gibbs PE, Bryan GW, Pascoe PL, Burt GR (1987) The use of the dog-whelk, Nucella lapillus, as an indicator of tributyltin (TBT) contamination. J Mar Biol Ass UK 67:507-523

Hagena W (1991) Herz- und Miesmuschelfischerei aus der Sicht der niedersächsischen Fischereiverwaltung. In: Schutzgemeinschaft Deutsche Nordseeküste (ed) Probleme der Muscheltıscherei im Wattenmeer. SDN, Wilhelmshaven

Knickmeyer R, Steinhart H (1989) Cyclic organochlorines in the whelks Buccinum undatum and Neptunea antiqua from the North Sea and the Irish Sea. Mar Poll Bull 20:433-437

Knickmeyer R, Steinhart H (1990) Seasonal variations and sex related differences of organochlorines in whelks (Buccinum undatum) from the German Bight. Chemosphere 20: $109-122$

Lauckner G (1980) Diseases of Mollusca: Gastropoda. In: Kinne $O$ (ed) Diseases of marine animals. Wiley \& Sons, Chichester, p 185-302

Matthiessen P, Waldock R, Thain JE, Milton S, Scorpe-Howe S (1991) Changes in perwinkle (Littorina littorea) population following the ban on TBT-based antifoulings on small boats. Comm Meet Int Counc Explor Sea. CM-ICES 1991/E:5

Mensink BP, Everaarts JM, Kralt J, ten Hallers-Tjabbes CC (1996b) Tributyltin exposure in early life stages induces the development of male sexual characteristics in the common whelk, Buccinum undatum. Mar Environ Res 42 $(1-4): 151-154$

Mensink BP, ten Hallers-Tjabbes CC, Kralt J, Freriks IL, Boon JP (1996a) Assessment of imposex in the common whelk, Buccinum undatum (L.) from the Eastern Scheldt, the Netherlands. Mar Environ Res 41 (4):315-325

Mensink BP, van Hattum B, Vethaak AD, Boon JP (1996c) The development of imposex in relation to organotin contamination in the common whelk, Buccinum undatum. Field observations in the Eastern Sheldt and experimental exposure in a laboratory study. Netherlands Institute for Sea Research (NIOZ), den Burg, Texel

Michaelis H (1993) Algen, schwarze Flecken und andere Probleme des Wattenmeeres. In: Schutzgemeinschaft Deutsche Nordseeküste (ed) Geht es der Nordsee besser? SDN, Wilhelmshaven, p 90-106

Mylnt UM. Tyler PA (1982) Effects of temperature, nutritive and metal stressors on the reproductive biology of Mytilus edulis. Mar Biol 67:209-223

Neudecker T (1990) Genutzte Muscheln und Schnecken. In: Lozán JL, Lenz W, Rachor E, Watermann B, v Westernhagen $H$ (eds) Warnsignale aus der Nordsee. Paul Parey, Berlin, p 165-175

Oehlmann J, Stroben E, Fioroni P (1992) The rough tingle Ocenebra erinaced (Gastropoda: Murcidae): an exhibitor 
of imposex in comparison to Nucella lapillus. Helgoländer Meeresunters 46:311-328

Reid DG (1986) Mainwaringia Nevill, 1985, a littorinid genus from asiatic mangrove forests as a case of protandrous hermaphroditism. J Mollusc Stud 52:225-242

Sachs L (1988) Statistische Methoden: Planung und Auswertung, 6. neubearb. u. erw. Auflage. Springer-Verlag, Berlin

Smith BS (1971) Sexuality in the American mud snail, Nassarius obsoletus Say. Proc Malac Soc Lond 39:377-378

Stroben E (1994) Imposex und weitere Effekte von chronischer TBT-Intoxikation bei einigen Mesogastropoden und Bucciniden (Gastropoda, Prosobranchia). Cuvillier, Gottingen

Stroben E, Brömmel C, Oehlmann J, Fioroni P (1992a) The genital systems of Trivia arctica and Trivia monacha (Prosobranchia: Mesogastropoda) and tributyltin induced imposex. Zool Beitr NF 34:349-374

Stroben E, Oehlmann J, Fioroni P (1992b) The morphological expression of imposex in Hinia reticulata (Gastropoda: Buccinidae): a potential biological indicator of tributyltin pollution. Mar Biol 113:625-636

Svennen C, Ruttanadakul N, Ardseungnern R, Singh HR, Tan KS, Mensink BP, ten Hallers-Tjabbes CC (1996) TBT in South East Asia-an emerging problem. First survey showing impact of TBT in marine eviroment of Malaysia and Thailand. Wallaceana $78: 1-13$

This article was submitted to the editor ten Hallers-Tjabbes CC (1979) Sexual dimorphism in BuCcinum undatum L. Malacologia 18:13-17

ten Hallers-Tjabbes CC (1996) Impact of TBT antifouling in open sea in Europe and South East Asia - risk and ecological consequences. Proceedings IMAS 96, Shipping and the Environment. Is Compromise Inevitable? London, 22-24 October 1996. The Institute of Marine Engineers, London, p 55-60

ten Hallers-Tjabbes CC, Boon JP (1995) Whelks (Buccinum undatum L.), dogwhelks (Nucella lapillus L.) and TBTa cause for confusion. Mar Poll Bull 30:675-676

ten Hallers-Tjabbes CC, Kemp JF, Boon JP (1994) Imposex in whelks (Buccinum undatum) from the open North Sea: relation to shipping traffic intensities. Mar Poll Bull 28: 311-313

ten Hallers-Tjabbes CC, Mensink BP, van Hattum B, Boon JP (1996) Impact of traditional antifouling in open sea, risk and ecological consequences. The present status of TBTcopolymer antifouling paints. Int Symp Den Haag, Directorate-General for Shipping and Marine Affairs and the Organotin Environmental Programme Association, The Hague, p 36-42

Uhler AD, Steinhauer WG, Durell GS, Wade MG (1984) Analysis of butyltin species in enviromental matrices. Method selection criteria, method performance and laboratory implementation. Batelle Ocean Sciences, Duxbury

Manuscript first received: January 30, 1997

Revised version accepted: April 11, 1997 